Marek Marczak

Uniwersytet w Białymstoku

\title{
Leksyka z zakresu wróżbiarstwa i czarów w Nowym wielkim dykcjonarzu Pierre'a Daneta i Dymitra Franciszka Koli
}

\section{Wprowadzenie}

Trójjęzyczny, francusko-łacińsko-polski Nowy wielki dykcjonarz Pierre'a Daneta i Dymitra Franciszka Koli, wydany w latach 1743-1745, to jedno z najważniejszych dzieł polskiej leksykografii XVIII wieku, liczące ponad 50 tys. haseł. Autorem pierwowzoru dykcjonarza był francuski zakonnik, łacinnik, hellenista, a przede wszystkim leksykograf - Pierre Danet, natomiast twórcą polskiej części - zasłużony nauczyciel kolegium pijarskiego, Dymitr Franciszek Kola. Dzieło Daneta-Koli nie cieszyło się szczególnym zainteresowaniem badaczy, choć nie zostało też zupełnie zapomniane [por. Urbańczyk 1979; Leszczyński 1978, 1987; Bochnakowa 1991; Walczak 1994]. W ostatnich latach uwagę słownikowi poświęcili m.in. Agnieszka Fluda-Krokos [2011], według której słownik Daneta-Koli jest wręcz niezbędnym źródłem do badań nad historią języka, a także Ryszard Mączyński [2013], zainteresowany ustaleniem wydania pierwowzoru stanowiącego podstawę opracowania dla polskiego tłumacza, oraz Irena Szczepankowska [2019], która rozważała definicje narracyjne w dykcjonarzu z perspektywy współczesnej.

Celem niniejszego artykułu jest analiza semantyczna leksyki z zakresu wróżbiarstwa i czarów, występującej w Nowym wielkim dykcjonarzu. Podstawę analizy materiału leksykalnego stanowi teoria pola semantycznego, rozumianego jako uporządkowany i zhierarchizowany zbiór wyrazów, pomiędzy którymi zachodzą różne relacje semantyczne [Pisarek 1967; Buttler 1967; Miodunka 1980; Tokarski 1984, 2013: 247-276; Grzegorczykowa 2001]. Analiza tak usystematyzowanego słownictwa ujawnia

funkcjonowanie leksemów w zespole, konkurencję i rywalizację składników na linii centrum - peryferie, ich selekcję: awans lub degradację, następnie 
ginięcie leksemów, to znowu pojawianie się innowacji leksykalnych i semantycznych, w sumie - nieustającą polskiej „myśli przędzę”. [Zajda 2010: 91]

Z ustaleń Haliny Wiśniewskiej wynika, że teoria pola wyrazowego jest skutecznym narzędziem opisu słownictwa z perspektywy diachronicznej [2010], wykorzystano ją w wielu opracowaniach dotyczących leksyki z różnych zakresów, m.in. w pracach dotyczących polszczyzny XVI [Jankowiak 2005; Lisowski 2018], XVII [Mączyński 2005], XVIII [Siekierska 1992; Szamryk 2016; Kuryłowicz 2020] i XIX wieku [Handke 2010].

Według WSJP czary to 'czynności polegające na wypowiadaniu specjalnych słów i wykonywaniu specjalnych działań, których celem jest wykorzystanie sił nadprzyrodzonych, by osiągnąc to, co wydaje się niemożliwe do zrobienia w świecie rzeczywistym'. W przytoczonej definicji podkreślony jest nie tylko aspekt rytualny praktyk czarodziejskich, ale również kwestia nadnaturalności takich działań. Czary mają więc powodować zaistnienie faktów, które wydają się niemożliwe w świecie rzeczywistym. Wróżbiarstwo z kolei to 'przepowiadanie przyszłości na podstawie interpretacji układu pewnych przedmiotów czy zjawisk bądź pod wpływem objawienia' [WSJP]. Przepowiadanie przyszłości jest działaniem, które nie zaburza naturalnego porządku rzeczy i nie wpływa na rzeczywistość, w przeciwieństwie do praktyk magicznych. Oba rodzaje obrzędów zaspokajają istniejące od wieków potrzeby zachowań, rytuałów czy praktyk różnego rodzaju ceremonii magicznych [Kracik 2012: 259-267].

W czasach saskich działania magiczne i zabobony stanowiły ważną część życia Polaków, co w zasadzie nie dziwi, ponieważ na przełomie XVII i XVIII wieku praktyki czarodziejskie i wróżbiarskie były codziennością w całej Europie. Według Zbigniewa Kuchowicza [1975: 103] przekonanie o wpływie świata nadprzyrodzonego na rzeczywistość było naturalne w owych czasach. Historyk podkreśla ponadto powszechność wróżbiarstwa, które stanowiło element codziennego życia mieszkańców Rzeczypospolitej pierwszej połowy XVIII wieku. Przepowiadano przyszłość m.in. ze snów, wosku, odgłosów natury czy kości [Kracik 2012: 215-216]. Wróżby odbywały się zazwyczaj w związku z jakąś ważną uroczystością lub początkiem jakiegoś okresu, np. nastaniem wiosny bądź ślubem, czyli wydarzeniami nierozerwalnie powiązanymi ze zwyczajnym biegiem życia [Kuchowicz 1975: 99-144]. Bardzo rozpowszechnione w czasach saskich były także praktyki magiczne, szczególną popularnością cieszyły się zwłaszcza czary miłosne. Miały one albo rozkochać kogoś w kimś, albo po prostu dodać komuś atrakcyjności. Za pomocą czarów sprowadzano również nieszczęście na nieprzyjaciół, częstą przyczyną takich działań był zawód sercowy [Kuchowicz 1975: 264-269]. Warto zazna- 
czyć, że w owych czasach zwykli ludzie nie rozgraniczali praktyk religijnych i magicznych [Kracik 2012: 216]. Trwający niemal siedem wieków proces chrystianizacji nie wyrugował całkowicie pogańskich zabobonów, zostały one raczej dostosowane do nowej, chrześcijańskiej rzeczywistości, a ukształtowany wcześniej sposób pojmowania świata, zawierający przekonanie o realnej mocy czarów i ich wpływie na życie człowieka, pozostał niezmieniony [Kracik 2012: 217]. Taki stan rzeczy był dobrze znany katolickim misjonarzom, którzy obrali sobie za cel korygowanie błędów w wierze. Szczególnie częstym miejscem organizacji misji ewangelizacyjnych były Kresy Wschodnie [Kuchowicz 1975: 100; Flaga 1981; Michalczuk 2016], co może świadczyć o tym, że tam właśnie pogańskie rytuały były najbardziej zakorzenione.

Znaczenie magii i wróżbiarstwa, tak mocno wyeksponowane w kulturze i obyczajowości epoki saskiej, powinno znaleźć odzwierciedlenie w języku, stąd też wydaje się interesujące sprawdzenie, czy i w jakim stopniu w ówczesnym języku polskim uwydatniona została wiara w zabobonne praktyki, właściwa XVIII-wiecznym nosicielom kultury polskiej.

\section{Material badawczy}

Podstawę analizy stanowi 60 jednostek słownikowych wyekscerpowanych z Nowego wielkiego dykcjonarza. Zgromadzony materiał przyporządkowano do dwóch pól wyrazowych - 24 jednostki leksykalne zaliczono do pola wróżBIARSTWO i 36 do pola CZARY. Znacząca część analizowanych leksemów to polisemy, np. wyraz czary występuje 6 razy w różnych powiązanych ze sobą znaczeniach. W takich wypadkach włączenie do badań francuskich wyrazów hasłowych, rzadziej też łacińskich, wydaje się konieczne, ponieważ umożliwia ustalenie poszczególnych znaczeń polskiej jednostki leksykalnej. W obrębie wskazanych pól wyróżniono subpola. W polu wróżBIARSTWO wyodrębniono subpola RODZAJE WRÓŻB OraZ OSOBY ZAJMUJĄCE SIĘ WRÓŻENIEM, w polu CZARY: RODZAJE CZARÓW, OSOBY ZAJMUJĄCE SIĘ CZARAMI OraZ NASTĘPSTWA CZAROWANIA. Klasyfikacja ma charakter autorski, dostosowany do potrzeb niniejszego szkicu.

\section{Pole wróżbiarstwo}

Autor polskiej części dykcjonarza przetłumaczył 25 różnych francuskich wyrazów hasłowych z pola semantycznego wróżBIARSTwo za pomocą 15 polskich określeń. W subpolu RODZAJE WRóżB znalazło się 11 wyrazów francuskich (augure, hydromantie, chiromance, auspices, aruspicine, pronostique, astrologie, auguration, divination, augurer, pronostiquer) i 8 polskich (wieszczba, wróżba, wróżenie, wieszczbiarstwo, wieszczbiarska nauka, wieszczenie, wiesz- 
czyć, wróżyć). Subpole OSOBY ZAJMUJĄCE SIĘ WRÓżBIARSTWEM składa się aż z 14 francuskich leksemów (aruspice, haruspice, augure, devin, pronostiqeur, interprete, devine, devineresse, divinatrice, chiromancien, chiromancienne, astrologue, enthousiasme, enthousiaste) i jedynie 7 polskich (wieszczek, wróżek, wieszczka, wróżka, gwiazdarz, duch, natchniony).

\subsection{Subpole RODZAJE WRóżB}

W części francuskojęzycznej występuje 11 leksemów nazywających rodzaje praktyk wróżbiarskich, te same informacje Kola oddał za pomocą 8 różnych wyrazów. W nazwach wieszczba, fr. augure 'wróżenie z głosu albo lotu ptactwa', wróżba, fr. hydromantie 'wieszczba wodna, wróżąc co przez wodę albo $\mathrm{z}$ wody' i wróżenie, fr. chiromance ' $\mathrm{z}$ ręki patrząc na różne linie po rękach' specyfika praktyki wróżbiarskiej została jasno wyrażona w polskiej definicji. Ustalenie znaczenia polskich nazw wieszczba, fr. auspices 'wróżki sposób' i wieszczbiarstwo, fr. aruspicine wymaga natomiast odniesienia się do wyrazów francuskich. Pierwszy wyraz dotyczy auspicji, czyli wróżenia z zachowań ptaków, drugi zaś haruspicji, czyli wróżenia ze zwierzęcych wnętrzności.

Kolejną jednostką leksykalną z omawianego subpola jest wyrażenie wieszczbiarska nauka; fr. astrologie, łac. astrologia divinans, którego znaczenie można wyeksplikować na podstawie łacińskiej nazwy gwiazdarska nauka, astrologia, fr. astrologie, łac. astrologia. W łacińskich leksemach widać rozróżnienie między współcześnie rozumianą astrologią (divinans - przewidujący, wróżący, przepowiadający) a astronomią. Polskie nazwy jeszcze wyraźniej różnicują znaczenie pomiędzy przepowiadaniem przyszłości z gwiazd (wieszczbiarska nauka) a badaniem ich (gwiazdarska nauka). Słownik notuje również bardziej ogólną nazwę określającą przepowiadanie przyszłości, a mianowicie wróżba, fr. pronostique 'wieszczba'.

Akt wróżbiarski dwukrotnie został określony przez Kolę jako wieszczenie, fr. auguration i wieszczenie, fr. divination 'wróżenie przyszłych rzeczy, wieszczbiarstwo nauka'. Danet definiuje wymienione hasła precyzyjniej: auguration jako 'wykonywanie auspicji' ${ }^{1}$, divination zaś jako 'czynność przepowiadania przyszłych rzeczy'2. We francuskich wyrazach hasłowych zauważalna jest relacja hiponimiczna pomiędzy auguration (wykonywaniem auspicji - rodzaju wróżby) a divination (przepowiadaniem przyszłości ogólnie). Polska część nie oddaje tej zależności. Słownik notuje ponadto bezokolicznik wieszczyć, fr. augurer 'wróżyć, przepowiadać co'. Interesującym tłumaczeniem wydaje

1 Fr. 'l'action d'augurer'.

2 Fr. 'l'action de deviner les choses à venir'. 
się wróżyć, fr. pronostiquer 'co wnosić sobie co z czego wróżąc wieszcząc', gdyż francuskie hasło już od XVI wieku używane było głównie w kontekście medycznym - tożsamym znaczeniowo ze współczesnymi polskimi czasownikami prognozować bądź rokować [DHLF: pronostiquer]. Podsumowując, na określenie różnych rodzajów wróżb Kola stosuje nazwy wieszczba i wróżba, a także wróżenie, wieszczenie, wieszczbiarstwo i wieszczbiarska nauka.

Polskie definicje wyrazów wieszczba i wróżba sugerują, że były one jak wcześniej w tym tekście używane wymiennie do określania różnych praktyk wróżbiarskich. Bez odniesienia do francuskiego wyrazu hasłowego bądź definicji nie da się zazwyczaj rozróżnić konkretnych rodzajów przepowiadania przyszłości. Leksem wieszczba notowany jest również w Mowniku... Troca, który rozróżnia wieszczbę z nieba, z powietrza czy z ptaków [MT]. Repertuar słownictwa $\mathrm{z}$ omawianego zakresu w przywołanym dziele ${ }^{3}$ może sugerować, że XVIII-wieczna leksyka dotycząca wróżbiarstwa i czarów była bardziej rozbudowana, niż to wynika ze słownika Daneta-Koli. Późniejszy słownik Samuela Bogumiła Lindego wyróżnia 'wróżbę ogniową' [SL] oraz 'wieszczby z fusów, z gwiazd, z powietrza, z nieba, z ptaków, z trzew bydlęcych' [Krótki 2015: 172]. Z kolei Słownik wileński definiuje wróżbiarstwo jako 'przepowiadanie przyszłości z pewnych znaków zewnętrznych, np. z lotu ptaków, z trzew bydlęcych, z położenia gwiazd', a wróżbę i wieszczbę synonimicznie jako 'wróżenie, przepowiadanie przyszłości ze znaków, wieszczenie, wieszczba' oraz 'przepowiednia, wróżba, zapowiednia przyszłości z pewnych znaków' [SWil].

Polski materiał leksykalny w słowniku Daneta-Koli jest mało urozmaicony w zakresie nazewnictwa praktyk wróżbiarskich. Kola tłumaczy nazwy francuskie za pomocą bardziej ogólnych określeń (wróżba, wieszczba, wróżenie), w wyniku czego osobliwy charakter niektórych sposobów przepowiadania przyszłości został zatarty w polskiej części słownika. W późniejszych wiekach zasób leksykalny w tym względzie został poszerzony, do polszczyzny weszło wiele wyrazów z greki i łaciny (np. chiromancja, auspicje), obecnych w materiale Daneta, a niewyróżnionych przez Kolę osobnymi nazwami.

3 Por. np.: czarnoksięski, czarnoksięstwo (czarnoksięstwem się bawić), czarnoksiężnik, czarowanie, czarownica, czarowniczy, czarowny (czarowne słowa na zaklinanie wężów, odczynianie chorób), czarownik, czaruję, czary (czary na zjednanie miłości u kogo), wiedma, wiedżma, wieszczba, wieszczbiarski, wieszczbiarz, wieszcze, wieszczek, wieszczka; podhasła, np.: czarnoksięski kamień, księga czarnoksięska, czarnoksięska nauka, czarowniczy kamień, wieszczba, wieszczenie z ptakow, ptaszowieszczenie, wieszczba z bydlęcych trzew [zob. Kuryłowicz 2018: 284]. 


\subsection{Subpole OSOBY ZAJMUJĄCE SIĘ WRÓŻBIARSTWEM}

Subpole to obejmuje 14 francuskich i jedynie 7 polskich jednostek leksykalnych. Jego charakterystyczną cechą jest polisemiczność polskich nazw. Kola za pomocą wyrazu wieszczek thumaczy pięć różnych leksemów francuskich. Dwa pierwsze: wieszczek, fr. aruspice 'kapłan rzymski, który przyszłe rzeczy opowiadał, przypatrując się wnętrznościom bydląt, które ofiarowano' oraz wieszczek, fr. haruspice ' $\mathrm{z}$ trzew bydlęcych co przepowiadający. Zabobon ${ }^{4}$ ' odnoszą się do tego samego rodzaju praktyk, można je zatem uznać za jeden leksem. Co więcej, francuskie wyrazy hasłowe aruspice i haruspice były stosowane wymiennie [DHLF: aruspice]. Kola stara się jednak wyróżnić pierwszy jako określenie historycznej pozycji społeczno-religijnej, drugi zaś stosuje tylko do opisu pogańskiej praktyki. Trzecie znaczenie tego słowa to wieszczek, fr. augure 'urząd, starego Rzymu który brał znaki uważając lot, albo żobanie ptactwa', podobnie jak w pierwszym przytoczonym przykładzie w definicji podkreślony został obywatelski aspekt pozycji wieszczącego. Wieszczek, fr. devin w znaczeniu 'co przyszłe rzeczy opowiada, wróżek' cechuje nieprecyzyjność i ogólnikowość, którą da się zaobserwować również we francuskiej części dykcjonarza. Danet określa devin jako kogoś, 'kto przepowiada przyszłe rzeczy $^{6}$. Warto zwrócić uwagę, że definicja Koli jest uzupełniona o wskazujące na synonimię słowo wróżek. Taką relację można zaobserwować w haśle wróżek7, fr. pronostiqeur 'wieszczek'.

Ostatnie hasło przetłumaczone w ten sam sposób to wieszczek, fr. interprete 'wróżek'. Ten sam francuski wyraz hasłowy służy do opisania leksemu tłomacz, fr. interprete 'wykładacz'. Jak można zauważyć, w tym wypadku to Kola stosuje słownictwo, które precyzyjniej opisuje sens pojęcia. Można podejrzewać, że autor polskiej części dykcjonarza różnicuje francuskie polisemy, jeżeli widzi ku temu powód.

Interesujące wydają się trzy nazwy przełożone na polski jako wieszczka: fr. devine 'wróżka, widma Baba', fr. devineresse 'cyganka' i fr. divinatrice 'wróżka'. Kola thumaczy trzy różne francuskie leksemy w ten sam sposób, można to jednak uzasadnić tym, że mają one to samo znaczenie. Francuskie leksemy różni jedynie forma wyrazowa, która nie ustabilizowała się do XVIII wieku [DHLF: devin], dlatego też Danet mógł umieścić te określenia w oddzielnych artykułach hasłowych. Zastanawiające są jednak definicje poszczególnych leksemów, w każdej podane są inne synonimy.

\footnotetext{
4 Kola uzupełnił definicję o słowo zabobon.

5 Żobać 'jeść, spożywać, edere, comedere' [SStp].

6 Fr. 'qui prédit les choses à venir'.

7 W słowniku: WROZKK, prawdopodobnie błąd typograficzny.
} 
Nieco odmiennym przypadkiem są formy zróżnicowane pod względem rodzaju gramatycznego wróżek, wróżka, fr. chiromancien, chiromancienne 'co wróży z patrzania na ręcz', gdzie polskie odpowiedniki francuskich haseł nie odnoszą się do specyficznego typu przepowiedni, tj. wróżenia z linii na dłoniach, ale są ogólniejsze. Do osoby zajmującej się szczególnym rodzajem praktyk odnosi się natomiast wyraz gwiazdarz, fr. astrologue 'co opowiada wypadki przyszłe rzeczy z gwiazd'. Ten przykład wydaje się potwierdzać to, że do XVIII wieku włącznie wyraz gwiazdarz służył do określenia zarówno badacza gwiazd, jak i wróżbity [Waniakowa 2003: 97].

Z osobą przepowiadającą przyszłość łączą się leksemy duch, fr. enthousiasme 'wieszczy co osobliwego i niezwyczajnego opowiadający, natchnienie prorockie' oraz natchniony, fr. enthousiaste 'duchem wieszczym'. Nawiązują one do antycznego rozumienia entuzjazmu, czyli opanowania przez boską esencję, które zostało wyeksponowane w definicjach wyrazów duch i natchniony. Od połowy XVII wieku francuski wyraz enthusiasme oznacza, podobnie jak współcześnie, stan wielkiej radości [DHLF: enthousiasme], to przesunięcie znaczeniowe nie zostało jednak zarejestrowane przez Daneta.

Z obserwacji materiału leksykalnego tworzącego subpole OSOBY ZAJMUJĄCE SIĘ WRÓżBIARSTWEM wynika, że zakres znaczeniowy wyrazów wróżek i wróżka jest tożsamy z zakresem określeń wieszczek, wieszczka. Zróżnicowanie osób zajmujących się rozmaitymi praktykami wróżbiarskimi, mocno zaakcentowane we francuskojęzycznej części dykcjonarza, nie znalazło odzwierciedlenia w polskim nazewnictwie. O rodzaju praktyki wróżbiarskiej, którą uprawia konkretny wróżbita, informuje wyłącznie polska definicja.

Formy żeńskie, które pojawiają się w analizowanym materiale, świadczą o tym, że praktykami magicznymi zajmowali się i mężczyźni, i kobiety. Co więcej, określenia wróżek i wieszczek wyszły z użycia wcześniej niż feminatywy. Jeszcze w XIX wieku wróżek był 'człowiekiem trudniącym się przepowiadaniem przyszłości z pewnych znaków' [SWil], z kolei wieszczek oznaczał 'mężczyznę przepowiadającego przyszłość z pewnych znaków'. Słownik Witolda Doroszewskiego notuje leksem wieszczek już z kwalifikatorem przestarzały [SJPDor], wieszczkę zaś z kwalifikatorem książkowy [SJPDor]. Wróżka natomiast od XVIII wieku do dzisiaj [WSJP] pozostaje głównym określeniem kobiety przepowiadającej przyszłość. WSJP wyróżnia ponadto wróżke profesjonalna oraz bajkowa. Pierwsza definiowana jest jako 'kobieta przepowiadająca przyszłość na podstawie odczytania znaczenia pewnych przedmiotów lub zjawisk', druga zaś jako 'kobieta, która dzięki zdobytej wiedzy tajemnej potrafi wywoływać zjawiska nadprzyrodzone oraz robić rzeczy nieosiągalne dla innych'. Jak można zauważyć, w definicji wróżki bajkowej występuje 
nieobecna w pierwszym rozumieniu informacja o nadprzyrodzonym wpływie na rzeczywistość, co znacznie poszerza zakres znaczeniowy leksemu, choć z zastrzeżeniem, że dotyczy on głównie bajek.

\section{Pole CZARY}

Do pola wyrazowego CZARY przyporządkowano 42 wyrazy francuskie, czyli prawie o połowę więcej niż w poprzednio omawianym polu. Kola z kolei użył 27 polskich określeń nazywających czary. Materiał podzielono na trzy subpola, z których dwa pierwsze to: RODZAJE CZARów, złożone z 19 wyrazów francuskich (maléfice, sorcelerie, necromence, necromancie, enchantement, filtre, venèfice, sortilège, diablerie, evocation, conjurations, contre-charme, enchanter, charmer, desenchanter, desensorceler, evoquer, invocation, conjurer) i 13 polskich (czarostwo, czary, czarownictwo, diabelstwo, wzywanie, zaklinania, odczynienie, czarować, oczarować, odczarować, wywoływać, wzywanie, zaklinać) oraz OSOBY ZAJMUJĄCE SIĘ CZARAMI, gdzie znalazło się 10 francuskich leksemów (magicien, magicienne, sorcier, sorcière, enchanteur, enchanteuse, enchanteresse, conjurateur, necromantien, necromantienne) i 4 polskie (czarownik, czarownica, mataczka, zaklinajacy). Jak nadmieniono na początku artykułu, czary są zjawiskiem, które zaburza naturalny porządek rzeczy. W związku z tym każda czynność magiczna będzie miała swoje konsekwencje i skutki uboczne. Rzekomy wpływ czarów na rzeczywistość znalazł odzwierciedlenie $\mathrm{w}$ języku, toteż wydaje się zasadne wydzielenie $\mathrm{z}$ analizowanego pola wyrazowego dodatkowego subpola - NASTĘPSTWA CZARów złożonego z 13 wyrazów francuskich (ensorcelement, ensorcelé, ensorcelée, sorcelerie, malefice, malefcié, possede un, possede une, obsession, energumène, fanatique, endiablé, endiablée) i 10 polskich (oczarowanie, oczarowany, oczarowana, szczarowanie, szczarowany, szczarowana, opętany, opętana, opętanie, szalony).

\subsection{Subpole RODZAJE CZARów}

Podobnie jak w wypadku pola wróżBIARSTwO, tak i w polu CZARY zachodzi dysproporcja między liczbami nazw stosowanych przez Daneta i Kolę. Danet używa różnorodnych określeń, które wprowadzają dyferencjację czarów na poziomie językowym, z kolei określenia Koli mają ogólniejszą treść i szerszy zakres znaczeniowy, jeden wyraz nazywa różne rodzaje praktyk magicznych. Ogólnym określeniem czarów w dykcjonarzu jest wyraz czarostwo, fr. maléfice 'czarodziejstwo, czary', zdefiniowany za pomocą dwóch synonimów. Ogólny charakter tego leksemu skorelowany jest ze znaczeniem francuskiego wyrazu 
hasłowego, który do XVIII wieku oznaczał swego rodzaju wykroczenie, zły występek, wpływ czy czary [DHLF: maléfice].

Kola praktyki magiczne nazywa także na pomocą leksemu czary, fr. sorcelerie 'czarodziejstwo', w definicji synonimicznej brak jednak odwołania do sił nadludzkich. Historycznie wyraz francuski odnosił się do czarów wykonywanych z pomocą diabła [DHLF: sorcier, sorcellerie]. Jako czary, czarownictwo Kola przekłada także fr. necromence, necromancie. Nie podaje jednak polskiej definicji tego leksemu, co trudno wytłumaczyć. Danet określa necromence, necromancie jako sztukę porozumiewania się z demonami, choć etymologia francuskiej nazwy wskazuje, że jest to praktyka polegająca na przepowiadaniu przyszłości przy pomocy zmarłych, taką informację zawiera także łacińska definicja stanowiąca część artykułu hasłowego - łac. 'divinatio per mortuos'.

Za pomocą wyrazu czary Kola thumaczy sześć wyrazów francuskich, odnoszących się do różnych szczegółowych praktyk magicznych. Czary, fr. enchantement to zarówno 'sczarowanie urzeczenie', jak i czary, fr. filtre 'na zadanie miłości zwłaszcza w trunku zadane'. Oba znaczenia są do siebie zbliżone, ale nie są tożsame. Francuskie enchantement odnosi się do magicznego wpływu na kogoś, niekoniecznie romantycznego [DHLF: enchantement], z kolei filtre w rozumieniu Daneta dotyczy tak zwanych eliksirów miłości ${ }^{8}$. W języku polskim dopiero na poziomie definicji została uwydatniona różnica między wyrazem czary jako 'sczarowanie urzeczenie', który jest bardziej ogólny, a nazwą czary 'na zadanie miłości zwłaszcza w trunku zadane', która wydaje się bardziej szczegółowa. Na poziomie nominacyjnym zależność ta w języku polskim jest niewidoczna.

Kolejne znaczenie leksemu czary, fr. venèfice to 'trucie przez czary'. W tym wypadku Kola nie wprowadził leksykalnego rozróżnienia między czarami, mającymi na celu jedynie wpływać na kogoś, a tymi, których zadaniem było sprowadzenie na kogoś nieszczęścia, czyli tak zwaną czarną magią [Kuchowicz 1975: 267]. Co ciekawe, francuski wyraz hasłowy określający trucie przez czary jest notowany kilkakrotnie w formie łacińskiej - veneficum już w Thezaurusie Knapiusza. Określa on takie polskie nazwy jak trucie kogo 'trucizny zadawanie abo zadawanie komu' czy czarowanie [TK]. Sam wyraz veneficum zdefiniowany został jako 'Trucie. Czary. Czarowanie', więc wpierw

8 Filtre [DHLF: filtre] rozumiany był głównie w kontekście sztuki alchemicznej w aspekcie współczesnego filtru czy filtrowania. Philtre z kolei [DHLF: philtre] jest zlatynizowanym hellenizmem, który został przyjęty w języku francuskim w znaczeniu 'napój magiczny mający spowodować uczucie miłości’. Forma wyrazowa filtre w drugiej połowie XVII i pierwszej połowie XVIII wieku zaczęła funkcjonować w obu znaczeniach, prawdopodobnie dlatego Danet notuje ją w dykcjonarzu. 
jako trucie, następnie jako czarowanie. Na marginesie warto zauważyć, że odwrotną zależnością cechują się nazwy osób praktykujących czary, czyli veneficus i venefica to najpierw 1. 'czarownik' i 1. 'czarownica', a dopiero później 2. 'truciciel' i 2. 'trucicielka' [TK]. Wskazana relacja między wymienionymi leksemami może być jedynie przypadkowa, zważywszy na charakter dawnych dzieł leksykograficznych.

Do określeń praktyk magicznych o działaniu destrukcyjnym należy zaliczyć również czary, fr. sortilège 'gusła czy czarodziejstwa sztuki szatańskie'. Przytoczona definicja, w przeciwieństwie do wymienionych wcześniej, informuje o wpływie szatana na akt magiczny. Rodzaj czarów, który angażuje siły nadludzkie, to diabelstwo, fr. diablerie 'czary', tu francuski wyraz hasłowy wprost odnosi się do działań inspirowanych bądź przypisywanych diabłu [DHLF: diablerie]. O obcym nadludzkim wpływie informuje ponadto definicja wyrazu czarować, fr. enchanter 'oczarować z diabłem narabiać'. Hasło oczarować, fr. charmer 'omamić skutek jaki dziwny wyprowadzić przez moc czarów albo czarta' również jest wyjątkowe, gdyż jako jedyne w tym subpolu odnosi się do konkretnego typu czynności. Być może precyzyjność definicji jest tu językowym wyróżnikiem wagi, jaką miały takie działania w ówczesnym czasie, co byłoby zgodne z ustaleniami historyków kultury [Kuchowicz 1975: 267].

Działania, których celem miało być odwracanie negatywnych skutków czarów, określa wyraz odczarować, fr. desenchanter 'odrobić odczynić czary', a także odczarować, fr. desensorceler 'odczyniać'. W tym wypadku francuski wyraz hasłowy desenchanter odnosi się do odczyniania specyficznego rodzaju czarów ${ }^{9}$, Kola jednak nie czyni rozróżnienia pomiędzy dwoma rodzajami przeciwdziałań magicznych. Z kolei wyraz odczynienie, fr. contre-charme 'czarów, czary na czary' służy do nazwania praktyk magicznych, których celem jest przeciwdziałanie czarom za pomocą czarów. Dykcjonarz nie rejestruje innych nazw rytuałów, które służą do walki ze skutkami czarów.

W subpolu można wyróżnić grupę leksemów nazywających przywoływanie sił nadludzkich. Określenia wywoływać, fr. evoquer 'przez czary diabły z piekła, albo duchy jakie', wzywanie, fr. evocation 'złych duchów zawołanie ich przez czary', wzywanie, fr. invocation 'czartów' oraz zaklinać, fr. conjurer 'złych duchów wyklinać ich' i zaklinania, fr. conjurations 'złych duchów y wypędzenia’ można uznać za synonimy, ponieważ odnoszą się do tego samego zjawiska przywoływania złych duchów, podobnie jak francuskie wyrazy hasłowe, które nazywają tę samą czynność [DHLF: invocation, evocation, conjuration].

9 Por. czary, fr. enchantement 'sczarowanie urzeczenie'. 


\subsection{Subpole OSOBY ZAJMUJĄCE SIE CZARAMI}

Dykcjonarz Daneta-Koli notuje stosunkowo niewiele określeń osób praktykujących czary. Ogólnym określeniem osób zajmujących się magią jest czarownik, fr. magicien 'co czarami narabia czarnoksiężnik' oraz czarownica, fr. magicienne. Notowany bez definicji czarownik, fr. sorcier i czarownica, fr. sorcière 'baba' są tłumaczeniem nieco innych francuskich wyrazów hasłowych, ale jak już nadmieniono wyżej ${ }^{10}$, autor polskiej części ich nie rozróżnia.

Czarownik, fr. enchanteur 'szalbierz, matacz, bałamut' nazywa także osoby praktykujące szczególny rodzaj magii, wyraz ten ma wariant żeński w postaci czarownica, mataczka, fr. enchanteuse ou enchanteresse 'baba bałamutnica' . Definicje nie odnoszą się jednak do nadnaturalnego aspektu czarów, ale do oszustwa i kłamstwa. Osobę praktykującą osobliwy typ czarów nazywa również leksem zaklinajacy, fr. conjurateur 'czarty'. W zgromadzonym materiale występują również czarownik i czarownica, fr. necromantien, necromantienne, których Kola i Danet nie opatrzyli definicją leksykalną ${ }^{11}$. Co ciekawe, tylko łacińska część artykułu hasłowego informuje o tym, że znaczenie wyrazów odnosi się do osób, które wywołują duchy zmarłych z grobów ${ }^{12}$.

\subsection{Subpole NASTĘPSTWA CZARÓW}

Słownik notuje cztery nazwy określające ogólny skutek praktyk magicznych. Są to oczarowanie, fr. ensorcelement 'szczarowanie', oczarowany, oczarowana, fr. ensorcelé, ensorcelée 'szczarowany' oraz szczarowanie, fr. sorcelerie 'omamienie urzeczenie' i szczarowany, szczarowana, fr. malefice, malefcié. Definicja synonimiczna obecna w pierwszych przykładach sugeruje, że analizowane nazwy funkcjonowały wymiennie.

Następstwem praktyk magicznych jest opętanie - Kola określa tym słowem pięć różnych francuskich haseł. Wśród nich wyróżnić można takie, które odnoszą się do opanowania człowieka przez nadludzką siłę, np. opętany, fr. possede un 'od złego ducha, nawiedzony, utrapiony', opętana, fr. possede une 'utrapiona' oraz opętanie, fr. obsession 'od czarta opanowanie'. Określenia opętany, opętana z fr. energumène 'bycie pod diabelskim wpływem' nie mają polskiej definicji. Wyraz szalony, fr. fanatique 'natchniony dziwnym duchem na zmysłach ruszony’ również odnosi się do wpływu jakiejś siły na człowieka, ale bez wskazania, czy jest to siła dobra, czy zła.

10 Por. 4.1. Pole RODZAJE CZARÓW.

11 Por. czary, czarownictwo, fr. necromence, necromancie.

12 Łac. „Qui ou quae evocat manes defunctorum vita. Qui manes ou animas mortuorium elicit. Qui animas è sepulchris elicit". 
Nazwą różniącą się od pozostałych pod względem semantycznym jest opętany i jego forma żeńska opętana, fr. endiablé, endiablée, definiowane jako 'który dziwa robi jak opętany'. Taka eksplikacja akcentuje raczej podobieństwo w sposobie zachowania do osoby opętanej niż sam skutek opętania. Zaskakuje ona szczególnie dlatego, że francuskie wyrazy hasłowe wprost odnoszą się do opętania przez diabła [DHLF: endiabler].

\section{Wnioski}

Analiza materiału leksykalnego tworzącego pole wyrazowe wRóżBIARSTwo wykazała, że w porównaniu z liczbą nazw francuskich liczba polskich określeń nazywających różnorodne typy wróżb była ograniczona, do ich opisu autor polskiej części dykcjonarza stosował zazwyczaj derywaty współrdzenne z leksemami wróżba i wieszczba, np. w subpolu RODZAJE WRóżB: wieszczba, wróżba, wróżenie, wieszczbiarstwo, wieszczbiarska nauka, wieszczenie, wieszczyć, wróżyć, a w subpolu OSOBY ZAJMUJĄCE SIĘ WRÓżBIARSTWEM: wieszczek, wróżek.

Charakterystyczne właściwości odmiennych praktyk magicznych zostały wyeksponowane w definicjach leksykalnych. Szczególnie wyczerpująco Kola opisał te jednostki słownikowe, które odnosiły się do rytuałów starożytnych, np. auspicji. Wydaje się, że może to mieć związek z nieco innym pojmowaniem i wartościowaniem dziedzictwa starożytnej Grecji i Rzymu oraz pogaństwa w ogóle. Takie podejście mógłby tłumaczyć fakt, że zakon pijarów, do którego należał Kola, promował dzieła starożytnych, m.in. wydając na potrzeby dydaktyki utwory Horacego czy Klaudiana Klaudiusza [Taraszkiewicz 2015: 99-154].

Konsekwencją mniejszej liczby nazw (w stosunku do leksemów francuskich) odnoszących się do wróżbiarstwa była ich wieloznaczność. Różnorodne desygnaty $\mathrm{z}$ tego zakresu tematycznego funkcjonowały w rzeczywistości pozajęzykowej, nie miały one jednak wyróżników na poziomie językowym w postaci osobnych nazw.

Niewielką część analizowanych wyrazów opatrzył Kola definicją wskazującą na konkretny rodzaj przepowiedni. Być może precyzyjniejszy charakter tych określeń, np. gwiazdarz, fr. astrologue bądź wróżenie, fr. chiromance, podkreśla powszechność bądź wagę konkretnej praktyki w ówczesnych zwyczajach. Informacje zawarte w definicjach sugerują ponadto, że wróżbiarstwo nie miało tak negatywnego odbioru jak czary. Przepowiadanie przyszłości, znajdowało się raczej w strefie niegroźnych przesądów niż destrukcyjnych działań [Pilaszek 2008: 64-66, 75-76]. 
Słownictwo z pola wyrazowego CZARY, podobnie jak to dotyczące wróżbiarstwa, cechuje niewielka różnorodność, choć odnoszą się one do bardzo dużego zbioru desygnatów - do przekładu 43 wyrazów francuskich zastosowano jedynie 23 polskie nazwy. Leksem czary i jego derywaty nazywają większość zjawisk w subpolu RODZAJE CZARÓw, poza nim słownik rejestruje też określenia: czarostwo, diabelstwo, wzywanie, zaklinania, odczynienie, wywoływać, wzywanie i zaklinać. OSOBY ZAJMUJĄCE SIĘ CZARAMI to głównie czarownik i czarownica, choć w materiale zarejestrowano też określenia zaklinający i mataczka. W subpolu NASTĘPSTWA CZARÓw można wyróżnić dwie grupy wyrazów - pierwsza odnosi się do niesprecyzowanego wpływu praktyk magicznych: oczarowanie, oczarowany, oczarowana, szczarowanie, szczarowany, szczarowana, druga zaś do wpływu jakiejś nadludzkiej istoty na praktykującego: opętany, opętana, opętanie, szalony.

Na podstawie definicji można wskazać dwa typy czarów: polegające na zdobywaniu czyjejś przychylności oraz truciu kogoś. Te dwa rodzaje praktyk były powszechne od wieków [Kracik 2012: 78-79], znalazły one także odzwierciedlenie w języku. Słownik staropolski notuje np. hasło trucina w 2. rozumieniu jako 'podawanie trucizny, czy też trucie' i w 3. jako 'szkodliwe czary, szkodliwe czynności magiczne’ [SStp]. Powiązanie czarów z trucicielstwem widoczne jest również u Knapiusza ${ }^{13}$, w Thesaurusie wyróżniono też osobno inny rodzaj praktyk, tj. czary na zjednanie miłości u kogo ${ }^{14}$ [TK].

W przeciwieństwie do pierwszego pola słownictwo z zakresu praktyk magicznych odnosi się nierzadko do czynności powszechnie uznanych za naganne. Niektóre analizowane określenia nazywają działania związane z przywoływaniem złych duchów bądź diabła. Inne wprost informują o potencjalnie śmiertelnym działaniu praktyk magicznych. Z kolei definicje leksemów zaklinanie czy wywoływanie mówią o wpływie istot nadludzkich na czary. Następstwem obcowania z ciemnymi siłami jest zazwyczaj opętanie, które notowane jest w dykcjonarzu wielokrotnie jako efekt praktykowania magii. Tego typu wpływ nie musi mieć tylko aspektu magicznego. Czysto religijna perspektywa opętania nie została jednak ujęta $\mathrm{w}$ analizowanym materiale.

Analiza polskich nazw w kontekście ich odpowiedników francuskich umożliwiła w niektórych wypadkach wskazanie zawiłości znaczeniowych, które zostały pominięte bądź niezdefiniowane wprost przez Kolę. Niektóre tłumaczenia francuskich wyrazów hasłowych są ogólne, często wyrażone wie-

13 Por. 4.1. Pole RODZAJE CZARÓW.

14 W łacińskiej części artykułu hasłowego określone jako philtrum, por. analizowane w tekście czary, fr. filtre 'na zadanie miłości zwłaszcza w trunku zadane'. 
lokrotnie używanymi nazwami, w innych zaś Kola różnicuje hasła, które we francuskim mają to samo znaczenie - trudno znaleźć tu jakąś zależność.

Reasumując, pole semantyczne obejmujące nazwy z zakresu czarów i wróżbiarstwa, wyekscerpowane z dykcjonarza Daneta-Koli, nie jest rozbudowane, co może nieco dziwić w kontekście obyczajowości epoki, w której wiara w zabobony stanowiła ważny składnik życia ówczesnych uczestników kultury polskiej.

Trudno dziś ustalić, dlaczego Kola w polskiej części dykcjonarza tak skąpo odzwierciedlił sferę, która w ówczesnych czasach stanowiła ważny element bytu. Można zaproponować dwa wyjaśnienia takiego stanu rzeczy. Po pierwsze, w ówczesnej polszczyźnie nie istniały formy hiponimiczne, które mogłyby zostać użyte przez Kolę w słowniku. Na marginesie można zauważyć, że tłumacz był skłonny do adaptacji leksemów francuskich w polskiej części dykcjonarza [Marczak 2020], jednak słownictwo z omawianego zakresu tematycznego charakteryzuje zaskakujący brak tego typu pożyczek językowych. Po drugie zaś, odpowiedzią może tu być także pedagogiczny, wychowawczy charakter słownika. Autor polskiej części dykcjonarza był zasłużonym kaznodzieją [Mączyński 2013: 233] oraz wykładowcą warszawskiego kolegium pijarskiego, gdzie nauczał filozofii, teologii i poetyki [Taraszkiewicz 2015: 128]. Zagadnienie funkcjonowania słownika jako pomocy dydaktycznej było jednym z elementów dyskusji pomiędzy Ryszardem Mączyńskim [2013: 244-245, 2014] a Anną Bochnakową [2014]. Badacz stanowczo zaprzeczał możliwości stosowania dykcjonarza w nauczaniu. Bochnakowa $\mathrm{z}$ kolei nie wykluczyła owej możliwości, podkreślając jednocześnie potrzebę istnienia takiej pomocy w XVIII wieku.

Przyjęcie stanowiska badaczki daje asumpt do przypuszczeń, że Kola celowo ograniczył polski materiał we wskazanym zakresie, gdyż starał się ustrzec uczniów przed tym, co uważał za zabobony bądź herezje. Co więcej, stosunkowo spora liczba pełniej zdefiniowanych wyrazów hasłowych odwołujących się do opętania i wpływu diabła na człowieka mogła mieć podobną właściwość edukacyjną - ostrzeżenia przed zagrożeniami wynikającymi ze stosowania takich praktyk. Bez całościowych badań i pełnego dostępu do danych dotyczących słownictwa XVII i XVIII wieku trudno jednoznacznie rozstrzygnąć, co miało większy wpływ na strukturę tego fragmentu słownictwa w dykcjonarzu: braki leksykalne czy zamysł autorski. Odpowiedź mogą przynieść jedynie szersze poszukiwania historycznojęzykowe, które wykraczają poza ramy tego niewielkiego szkicu. 


\section{Bibliografia}

Stowniki (wraz ze stosowanymi skrótami)

Danet Pierre, Nouveau grand dictionnaire... (1743-1745), przeł. Franciszek Kola, t. 1-2, Warszawa.

DHLF - Rey Alain, red. (2010), Dictionnaire historique de la langue française, Paris. MT - Troc Michał Abraham (1764), Nowy dykcjonarz, to jest Mownik polsko-niemiecko-francuski, Lipsk.

SJPDor - Doroszewski Witold, red. (1958-1969), Słownik języka polskiego, t. 1-11, Warszawa.

SL - Linde Samuel Bogumił (1807-1814), Słownik języka polskiego, t. 1-6, Warszawa. SStp - Urbańczyk Stanisław, red. (1953-2002), Słownik staropolski, t. 1-11, Wrocław. SWil -Zdanowicz Aleksander i in., red. (1861), Słownik języka polskiego, Wilno.

TK - Knapski Grzegorz (1621), Thesaurus polono-latino-graecus seu promptuarium lingua Latinae et Graece [...], Kraków.

WSJP - Żmigrodzki Piotr, red., Wielki słownik języka polskiego PAN, wsjp.pl [dostęp: 19 czerwca 2021].

\section{Literatura}

Bochnakowa Anna (1991), Le Nouveau grand dictionnaire françois, latin et polonois et sa place dans la lexicographie polonaise, Kraków.

Bochnakowa Anna (2014), Kilka uwag po lekturze artykułu Ryszarda Maczyńskiego „Jak pijarzy dykcjonarz Daneta wydawali (czyli o pożytku sięgania do źródeł)”, „Hereditas Monasteriorum”, t. 4, s. 401-405.

Buttler Danuta (1967), Koncepcja pola znaczeniowego, „Przegląd Humanistyczny”, t. 2, s. 41-59.

Flaga Jerzy (1981), Jezuickie misje ludowe w latach 1754-1770 w świetle liczb, „Roczniki Humanistyczne”, t. 29, s. 173-198.

Fluda-Krokos Agnieszka (2011), Nowy wielki dykcjonarz J. Mći X. Daneta opata francusko-łacińsko-polski... (1743-1745) - niezbędne źródło do historii języka polskiego, w: Badania historycznojezzykowe Stan, metodologia, perspektywy, red. Bogusław Dunaj, Maciej Rak, Kraków, s. 83-90.

Grzegorczykowa Renata (2001), Wprowadzenie do semantyki językoznawczej, Warszawa.

Handke Kwiryna (2010), Pole semantyczne barw fioletu w twórczości Stefana Żeromskiego, „Studia z Filologii Polskiej i Słowiańskiej”, t. 45, s. 49-64.

Jankowiak Lucyna Agnieszka (2005), Stownictwo medyczne Stefana Falimirza, Warszawa.

Kracik Jan (2012), Chrześcijaństwo kontra magia. Historyczne perypetie, Kraków. 
Krótki Zuzanna (2015), Przepowiednia w historii języka polskiego, „Etnolingwistyka. Problemy Języka i Kultury", t. 27, s. 167.

Kuchowicz Zbigniew (1975), Obyczaje staropolskie, Łódź.

Kuryłowicz Beata (2018), Słownik historyczny jako źródło do rekonstrukcji dawnych sposobów myślenia o świecie, w: Historia języka w XXI wieku. Stan i perspektywy, red. Magdalena Pastuch, Mirosława Siuciak, Katowice, s. 277-286.

Kuryłowicz Beata (2020), Struktura znaczeniowa słownictwa anatomicznego w „,Nowym Dykcjonarzu” M. A. Troca, „Białostockie Archiwum Językowe”, t. 20, s. $119-133$.

Leszczyński Zenon (1978), W sprawie datowania pożyczek leksykalnych, w: Z polskich studiów slawistycznych. Seria 5. Prace na VIII Międzynarodowy Kongres Slawistów w Zagrzebiu 1978, Warszawa, s. 263-269.

Leszczyński Zenon (1987), O stownictwie polskiej wersji Daneta, „Rozprawy Komisji Językowej Łódzkiego Towarzystwa Naukowego", t. 32, s. 155-161.

Lisowski Tomasz (2018), Hiponimizacja polskich ekwiwalentów greckich leksemów z pola semantycznego DZIECKO w Nowym Testamencie Biblii Jakuba Wujka (1599), w: Filologia jako porzadkowanie chaosu. Studia nad językiem i tekstem. Ad honorem Professoris Marci Cybulski, red. Ewa Woźniak, Anna Lenartowicz-Zagrodna, Łódź, s. 183-200.

Mączyński Maciej (2005), Językowy obraz XVII-wiecznego klasztoru sióstr norbertanek w Krakowie na Zwierzyńcu, Kraków.

Mączyński Ryszard (2013), Jak pijarzy dykcjonarz Daneta wydawali (czyli o pożytku sięgania do źródet ), „Hereditas Monasteriorum”, t. 2, s. 219-251.

Mączyński Ryszard (2014), W odpowiedzi Pani Profesor Annie Bochnakowej, „Hereditas Monasteriorum”, t. 4, s. 405-408.

Marczak Marek (2020), Polskie adaptacje łacińskich i francuskich nazw miejscowych w „Nowym wielkim dykcjonarzu” Pierre'a Daneta i Dymitra Franciszka Koli, „Linguodidactica”, t. 24, s. 159-171.

Michalczuk Agnieszka (2016), Religia i religijność Polaków w obserwacjach francuskich podróżników w Rzeczypospolitej XVII wieku, „Poznańskie Studia Slawistyczne", s. 313.

Miodunka Władysław (1980), Teoria pól językowych: społeczne i indywidualne ich uwarunkowania, Warszawa - Kraków.

Pilaszek Małgorzata (2008), Procesy o czary w Polsce w wiekach XV-XVIII, Kraków.

Pisarek Walery (1967), Pojęcie pola wyrazowego i jego użyteczność w badaniach stylistycznych, „Pamiętnik Literacki”, t. 58/2, s. 483-516.

Siekierska Krystyna (1992), Rzeczywistość w słownikach Knapiusza i Troca, „Prace Filologiczne", t. 37, s. 259-268. 
Szamryk Konrad Kazimierz (2016), Język rękopiśmiennych kazań Krzysztofa Kluka, Białystok.

Szczepankowska Irena (2019), Zalety modelu objaśniania znaczeń w osiemnastowiecznym dykcjonarzu Piotra Daneta i Franciszka Koli z perspektywy współczesnej semantyki i leksykografii, ,Język Polski”, s. 72-83.

Taraszkiewicz Jacek (2015), Pierwsze stulecie Zakonu Pijarów na ziemiach Rzeczpospolitej Obojga Narodów (1642-1740), Gdańsk.

Tokarski Ryszard (1984), Struktura pola znaczeniowego (studium językoznawcze), Warszawa.

Tokarski Ryszard (2013), Światy za słowami. Wykłady z semantyki leksykalnej, Lublin.

Urbańczyk Stanisław (1979), Polskie stowniki oświeceniowe, w: tenże, Prace z dziejów języka polskiego, Wrocław.

Walczak Bogdan (1994), Nowe prace o polskich słownikach osiemnastowiecznych, w: Studia romanica in honorem Stanislai Gniadek. Referaty z sesji naukowej zorganizowanej $w$ dniu 16 października 1992 r. dla uczczenia pamięci Profesora Gniadka, red. Henryk Misterski, Józef Sypnick, Poznań, s. 45-57.

Waniakowa Jadwiga (2003), Polska naukowa terminologia astronomiczna, Kraków.

Wiśniewska Halina (2010), Leksykalne pole semantyczne metoda opisu XVII-wiecznej rzeczywistości, „Językoznawstwo: współczesne badania, problemy i analizy językoznawcze", t. 4, s. 37-49.

Zajda Aleksander (2010), Historia języka polskiego dzisiaj. Możliwości, zadania $i$ postulaty $w$ zakresie badań nad historia słownictwa polskiego, „LingVaria”, t. 10 , s. $75-101$.

Marek Marczak

\section{The Lexis of Divination and Witchcraft in Nowy Wielki Dykcjonarz by Pierre Danet and Dymitr Franciszek Kola}

The paper aims to investigate Polish lexis belonging to the semantic fields of DIVINATION and WITCHCRAFT. The material was excerpted from the 18th-century trilingual Nowy wielki dykcjonarz (New grand dictionary). The semantic fields under analysis were divided into subfields. In the case of DIVINATION, the subfields of DIVINATION PRACTISES and PEOPLE FORETELLING THE FUTURE were identified. In turn, WITCHCRAFT was subdivided into MAGICAL PRACTICES, PEOPLE PRACTISING MAGIC and EFFECTS OF MAGIC. The analysis of the retrieved material suggests that the number of individual lexemes is relatively small and usually polysemic, which appears to contradict the popularity and prevalence of divination 
and witchcraft in the 18th-century Polish-Lithuanian Commonwealth as established by cultural historians. The supposed misrepresentation of the semantic fields under scrutiny may reflect the didactic nature of the Polish part of the dictionary.

KEYWORDS: historical lexicology; 18th century; Danet-Kola Dictionary; Dymitr Franciszek Kola; Pierre Danet; sorcery; divination.

mgr Marek Marczak [ORCID: 0000-0002-5662-2904] - doktorant językoznawstwa w Szkole Doktorskiej Nauk Humanistycznych na Uniwersytecie w Białymstoku; zainteresowania badawcze: leksykologia historyczna, semantyka leksykalna, językowy obraz świata. 